\title{
Levels of the natural hormones $17 \beta$-oestradiol and testosterone in serum of cattle: results from population studies in Poland
}

\author{
Barbara Woźniak, Sebastian Witek, Iwona Matraszek-Żuchowska, \\ Alicja Kłopot, Andrzej Posyniak \\ Department of Pharmacology and Toxicology \\ National Veterinary Research Institute, 24-100 Pulawy, Poland \\ bwozniak@piwet.pulawy.pl
}

Received: June 21, 2016

Accepted: November 23, 2016

\begin{abstract}
Introduction: The present study is a comprehensive overview of the natural occurrence of $17 \beta$-oestradiol and testosterone in serum of cattle in Poland. Material and Methods: The serum samples $(n=826)$ were collected from cattle within five years. The samples were examined for the presence of oestradiol and testosterone using ELISA or gas chromatography with mass spectrometry. Results: In 98 samples (24\%) 17ß-oestradiol was detected above decision limits of applied methods, including five samples over the recommended concentration of $0.1 \mu \mathrm{g} \mathrm{L}-1$. Of the serum samples taken from cows ( $\leq 18$ months of age), 95 and 99 percentiles of the animals had $17 \beta$-oestradiol concentration below 0.027 and $0.086 \mu \mathrm{g} \mathrm{L}{ }^{-1}$ and of samples from cows over 18 months of age - below 0.059 and $0.125 \mu \mathrm{g} \mathrm{L}^{-1}$ respectively. Calculated values for bulls ( $\leq 18$ months of age) were 0.025 and $0.034 \mu \mathrm{g} \mathrm{L} \mathrm{L}^{-1}$ and for the animals older than 18 months of age -0.035 and $0.041 \mu \mathrm{g} \mathrm{L}^{-1}$. The natural presence of testosterone was detected in 201 serum samples $(48.7 \%)$. According to the obtained data, $95 \%$ and $99 \%$ of cows ( $\leq 18$ months of age) serum samples had testosterone concentration below 0.05 and $0.23 \mu \mathrm{g} \mathrm{L}^{-1}$ and the animals over 18 months of age -0.30 and $0.49 \mu \mathrm{g} \mathrm{L}{ }^{-1}$, respectively. For bulls these values did not depend on the age of the animals and were in the ranges of $5-6.3 \mu \mathrm{g} \mathrm{L}^{-1}(95 \%)$ and $11.4-12.1 \mu \mathrm{g} \mathrm{L} \mathrm{L}^{-1}$ (99\%). Conclusion: Our study showed that the threshold values for these hormones in plasma of cattle designated years ago are correct, but they need to be supplemented for animals older than 18 months.
\end{abstract}

Keywords: cattle, $17 \beta$ - oestradiol, testosterone, natural levels, Poland.

\section{Introduction}

The natural steroids have been used in animal production for several years for anabolic purposes in order to increase growth of muscle mass and feed efficiency (15). However, only a few compounds have been found to have practical application in growth regulation and they include the most potent of naturally occurring oestrogen - $17 \beta$-oestradiol and the primary androgen - testosterone. In practice, their application is almost limited to ruminants and they are most effective in animals with low endogenous sex hormone production (12). Natural steroids are usually administered to the animals in the form of implants containing predominantly synthetic steroid esters rapidly hydrolysed in vivo into substances which are also endogenously present in urine. The $17 \beta$-oestradiol and testosterone as such or as esters are components of implants: Compudose, Implix BF, Synovex $\mathrm{H}$, and Implus $\mathrm{H}$ available in USA, Canada, and countries that allow the use of hormones to improve the rate of weight gain of slaughtered animals (19). In the European Union the use of hormonal growth promoters in animal production has been prohibited since 1988 (3). As a consequence of this regulation, a systematic control of residues of anabolic compounds in tissues of slaughter animals and food of animal origin by the EU countries and food exporting countries to Europe is required. Since 1996, the principles of examinations targeted at detecting risks to human health have been set out in Council Directive 96/23/ EC (4). According to it, control of natural hormones belonging to group A3 of steroid substances which have anabolic effect is mandatory. There are numerous methods for determining the level of natural hormones in different biological matrices, including immunological and 
chromatographic methods $(2,13,8,11,21,23)$. However, differentiation between naturally occurring $17 \beta$-oestradiol and testosterone and these hormones present after treatment on the basis of residue concentration measurements still remains problematic. Currently, only limited technical possibilities are available to prove abuse of natural hormones on the basis of analyses of biological samples for the parent compounds or their metabolites. The direct detection of steroid esters in plasma or hair (20) or the use of isotope ratio mass spectrometry in combination with gas chromatography (GC/C/IRMS) can be applied to confirm the abuse of certain endogenous steroids (10), but these methods are not currently widely used in food surveillance. Whether the hormone is exogenous or of natural origin can be determined based on knowledge of marker metabolites, yet only a few of those have been discovered so far (7). Therefore, the majority of methods that have been developed in this field rely on steroid exceeding concentration thresholds as a means of detecting their abuse $(17,18)$. Due to the high variations among concentrations of testosterone in bovine urine under physiological conditions and limited data on its natural level, no acceptable ranges for this hormone are established.

The ratio between $17 \beta$-testosterone and $17 \alpha-$ testosterone concentrations in urine used as an indicator for abuse in human and horse doping cannot be used in cattle, as shown by Angeletti and co-workers (1). Therefore the matrix of choice for testosterone abuse examination is serum or plasma. In 1992, the EC report edited by Heitzman (9) proposed the maximum level for testosterone and $17 \beta$-oestradiol in bovine plasma dependent on sex and age, and these values for testosterone remained the officially recommended values until the present day. For non-pregnant cows $\leq 18$ months of age the recommended threshold value for testosterone is $0.5 \mu \mathrm{g} \mathrm{L} \mathrm{L}^{-1}$, while for male animals younger than 6 months it is $10 \mu \mathrm{g} \mathrm{L}^{-1}$, and for animals aged 6-18 months the concentration of $30 \mu \mathrm{g} \mathrm{L^{-1 }}$ was adopted. According to this report the maximum level for natural $17 \beta$-oestradiol in plasma of cattle below 18 months of age was set at $0.04 \mu \mathrm{g} \mathrm{L}^{-1}$, but in 2007 the CRL Guidance Paper (5) was recommended to increase this value to $0.1 \mu \mathrm{g} \mathrm{L}^{-1}$. It should be emphasised that the above criteria apply to cattle under 18 months of age, and there is no reference value for older animals. In the literature, there is very limited data regarding endogenous levels of oestradiol and testosterone in different matrices. Thus the aim of the current study was to establish the level of naturally occurring $17 \beta$ oestradiol and 17 $\beta$-testosterone in serum of cattle in Poland in order to designate screening thresholds for detection of the abuse of these steroids.

\section{Material and Methods}

Serum samples. The bovine serum samples were obtained within the frame of Polish residue control programme. The samples were collected from both animals living on farm and from animals intended for slaughter. Serum samples were obtained from 448 cows of $1-168$ months of age and from 378 bulls of $1-48$ months of age. The information about cattle breed, physiological condition, and feeding system of the animals was not available. At the laboratory, the serum samples were stored below $-18^{\circ} \mathrm{C}$ and thawed before analysis.

Reagents and chemicals. Standards of $17 \beta$ oestradiol (min. 98\%), 17 $\beta$-testosterone (98\%), the deuterated internal standards of 17 $\beta$-oestradiol-d3 (>95\%) and $17 \beta$ testosterone-d2 (>95\%) were obtained from RIKILT (Institute of Food Safety, the Netherlands). All standards were stored in accordance with the recommendations of the certificates. Primary standard stock solutions were prepared in methanol at a concentration of $10 \mu \mathrm{g} \mathrm{L}^{-1}$ and were stored below $-18^{\circ} \mathrm{C}$. Working solutions with a concentration of $1.0 \mu \mathrm{g} \mathrm{L}^{-1}, 0.1$ $\mu \mathrm{g} \mathrm{\textrm {L } ^ { - 1 }}$, and $0.01 \mu \mathrm{g} \mathrm{\textrm {L } ^ { - 1 }}$ were prepared by appropriate dilution of the stock solutions with methanol. All solutions were stored at about $4^{\circ} \mathrm{C}$ (range $2-8^{\circ} \mathrm{C}$ ) for no longer than six months. All chemicals were of high purity quality. Solvents: petroleum ether, tert-butyl methyl ether and methanol (resi grade) were purchased from Mall Baker (the Netherlands), isooctane (GC grade) and heptafluorobutyric anhydride (HFBA) were obtained from Sigma-Aldrich (Germany). ELISA kits Ridascreen 17 $\beta$ oestradiol and Ridascreen testosterone were from R-Biopharm AG (Germany).

Methods. Serum samples were analysed by ELISA (236 samples) according to the manufacturer's instruction and by GC-MS (590 samples) as described by Woźniak et al. (22). Briefly, in both analytical protocols, hormones were extracted from serum samples with a mixture of tertbutyl methyl ether/petroleum ether (30:70, v/v). After phase separation, the tube contents were centrifuged and frozen at $<-18^{\circ} \mathrm{C}$ for $1.5-2 \mathrm{~h}$. Then, the organic phase was decanted and evaporated to dryness under a stream of nitrogen. The residue was dissolved in dilution buffer and tested by ELISA, or after the derivatisation with HFBA, and analysed by GC-MS. For each analytical batch calibration curve was prepared over analyte concentration range. The $17 \beta$-oestradiol and testosterone determined by GC-MS were quantified by using internal standard technique. In each series of analysis, spiked samples were tested to verify the quality of the results. Both methods used were accredited and positively verified in proficiency testing and interlaboratory comparisons. The performance of the methods for $17 \beta$-oestradiol and testosterone detection in bovine serum samples is presented in Table 1.

\section{Results}

The summary of statistical data for the concentrations of $17 \beta$-oestradiol and testosterone in cows and bulls are given in Tables 2 and 3, while graphical presentation of the data obtained is shown in the form of histograms in Figs 1 and 2. 
Table 1. Method parameters for $17 \beta$ - oestradiol and 17 $\beta$ - testosterone detection in bovine serum samples

\begin{tabular}{|c|c|c|c|}
\hline Parameter & & $17 \beta$ - oestradiol & $17 \beta$ - testosterone \\
\hline & \multicolumn{3}{|c|}{ GC-MS } \\
\hline \multirow[t]{3}{*}{ Calibration curves } & correlation coefficient & 0.9966 & 0.9913 \\
\hline & slope & 0.3437 & 0.2130 \\
\hline & intercept & -0.0293 & 0.2000 \\
\hline Decision limit & $\mathrm{CC} \alpha\left(\mu \mathrm{g} \mathrm{L}^{-1}\right)$ & 0.011 & 0.06 \\
\hline Detection capability & $\mathrm{CC} \beta\left(\mu \mathrm{g} \mathrm{L}^{-1}\right)$ & 0.018 & 0.10 \\
\hline Repeatability & C.V. $(\%)$ & 19.2 & 9.8 \\
\hline Reproducibility & C.V. $(\%)$ & 25.8 & 11.8 \\
\hline Recovery & $(\%)$ & 99.9 & 110.8 \\
\hline \multirow[t]{2}{*}{ Uncertainty } & $\mathrm{U}(\%)$ & 13.2 & 8.6 \\
\hline & \multicolumn{3}{|c|}{ ELISA } \\
\hline Decision limit & $\mathrm{CC} \alpha\left(\mu \mathrm{g} \mathrm{L}^{-1}\right)$ & 0.013 & 0.03 \\
\hline Detection capability & $\mathrm{CC} \beta\left(\mu \mathrm{g} \mathrm{L}^{-1}\right)$ & 0.024 & 0.06 \\
\hline Repeatability & C.V. $(\%)$ & 23.5 & 9.9 \\
\hline Reproducibility & C.V. $(\%)$ & 23.5 & 13.7 \\
\hline Recovery & $(\%)$ & 92.5 & 93.0 \\
\hline Uncertainty & $\mathrm{U}(\%)$ & 12.2 & 10.7 \\
\hline
\end{tabular}

Table 2. Specific population parameters for bovine serum $17 \beta$ - oestradiol

\begin{tabular}{|c|c|c|c|c|}
\hline \multirow{3}{*}{$\begin{array}{l}\text { Compound } \\
\text { Gender } \\
\text { Age (months) }\end{array}$} & \multicolumn{4}{|c|}{$17 \beta$ - oestradiol } \\
\hline & \multicolumn{2}{|c|}{ Cows } & \multicolumn{2}{|c|}{ Bulls } \\
\hline & $0-18$ & $>18$ & $0-18$ & $>18$ \\
\hline Number of samples tested (n) & 65 & 153 & 96 & 99 \\
\hline$<\mathrm{CC} \alpha$ & 55 & 110 & 78 & 72 \\
\hline$>0.100 \mu \mathrm{g} \mathrm{L}^{-1}(\mathrm{RC})$ & 1 & 4 & 0 & 0 \\
\hline $\operatorname{Max}\left(\mu \mathrm{g} \mathrm{L}^{-1}\right)$ & 0.165 & 1.12 & 0.034 & 0.049 \\
\hline $\operatorname{Mean}\left(\mu \mathrm{g} \mathrm{L}^{-1}\right)$ & 0.006 & 0.016 & 0.003 & 0.006 \\
\hline Median $\left(\mu \mathrm{g} \mathrm{L}^{-1}\right)$ & 0 & 0 & 0 & 0 \\
\hline s.d. $\left(\mu \mathrm{g} \mathrm{L}^{-1}\right)$ & 0.022 & 0.093 & 0.008 & 0.012 \\
\hline $95 \%$ Centile $\left(\mu \mathrm{g} \mathrm{L}^{-1}\right)$ & 0.027 & 0.059 & 0.025 & 0.035 \\
\hline $99 \%$ Centile $\left(\mu \mathrm{g} \mathrm{L}^{-1}\right)$ & 0.086 & 0.125 & 0.034 & 0.041 \\
\hline
\end{tabular}

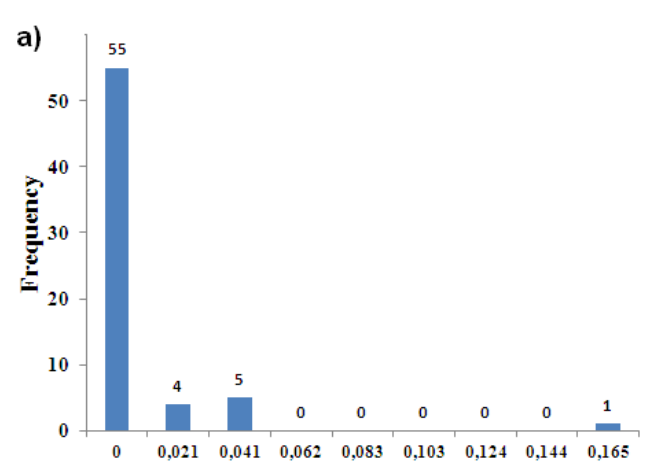

b)

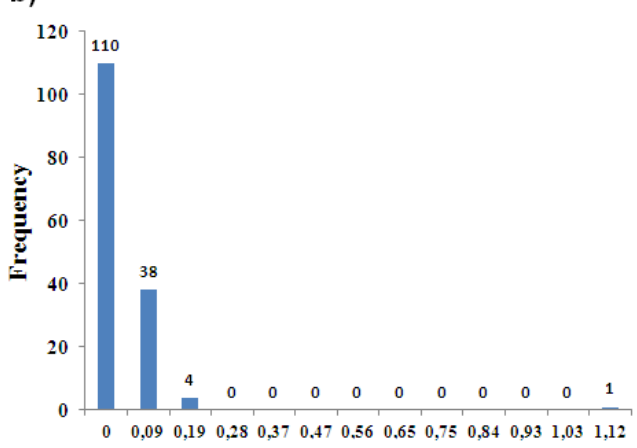

$\mu \mathrm{g} \mathrm{L}$

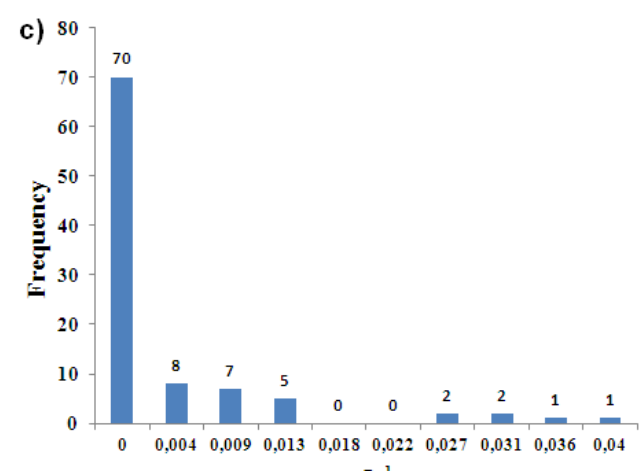

$\mu \mathrm{g} \mathrm{L}^{-1}$

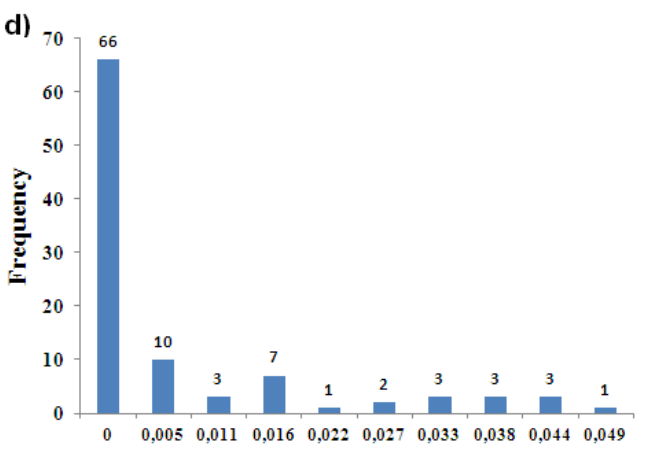

$\mu \mathrm{g} \mathrm{L}^{-1}$

Fig.1. Histogram of $17 \beta$-oestradiol concentrations in a) cows $\leq 18$ months of age; b) cows $>18$ months of age; c) bulls $\leq 18$ months of age; d) bulls $>18$ months 

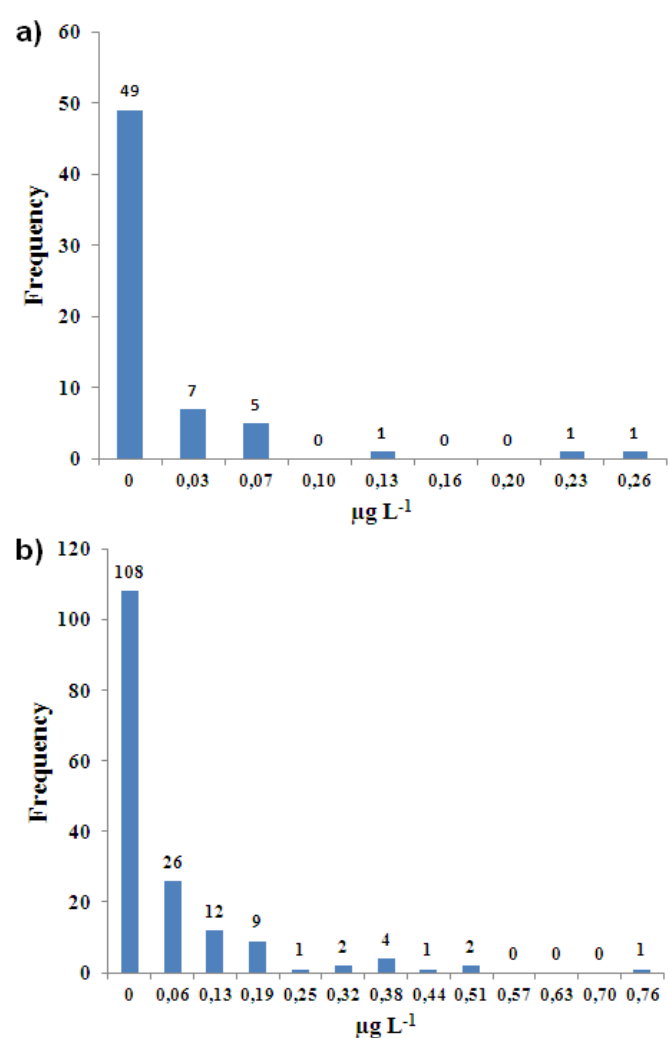
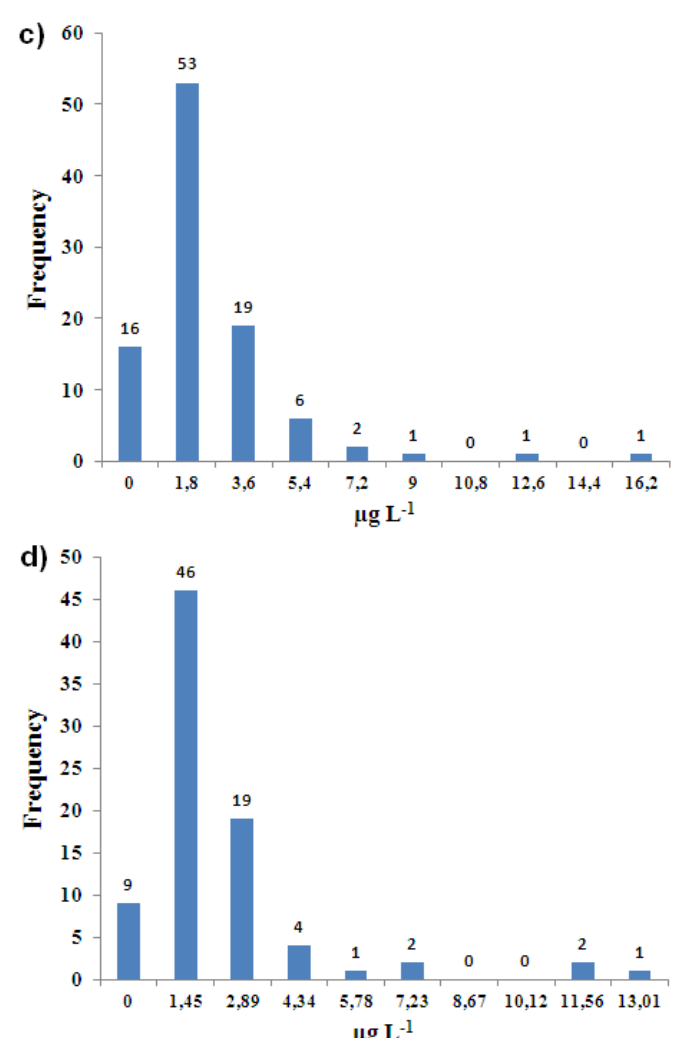

Fig. 2. Histogram of $17 \beta$-testosterone concentrations in a) cows $\leq 18$ months age; b) cows $>18$ months of age; c) bulls $\leq 18$ months of age; d) bulls $>18$ months of age

Table 3. Specific population parameters for the dataset of bovine serum 17 $\beta$ - testosterone

\begin{tabular}{|c|c|c|c|c|}
\hline \multirow{3}{*}{$\begin{array}{l}\text { Compound } \\
\text { Gender } \\
\text { Age (months) }\end{array}$} & \multicolumn{4}{|c|}{$17 \beta$-testosterone } \\
\hline & \multicolumn{2}{|c|}{ Cows } & \multicolumn{2}{|c|}{ Bulls } \\
\hline & $0-18$ & $>18$ & $0-18$ & $>18$ \\
\hline Number of samples tested (n) & 64 & 166 & 99 & 84 \\
\hline$<\mathrm{CC} \alpha$ & 51 & 127 & 22 & 12 \\
\hline$>0.5 \mu \mathrm{g} \mathrm{L}^{-1}(\mathrm{RC}$ for cows $\leq 18$ months $)$ & 0 & 1 & & \\
\hline$>10 \mu \mathrm{g} \mathrm{L}^{-1}(\mathrm{RC}$ for bulls $\leq 6$ months $)$ & & & 2 & 3 \\
\hline$>30 \mu \mathrm{g} \mathrm{L}^{-1}(\mathrm{RC}$ for bulls $<6-18$ months $)$ & & & 0 & 0 \\
\hline $\operatorname{Max}\left(\mu g \mathrm{~L}^{-1}\right)$ & 0.26 & 0.76 & 16.2 & 13.0 \\
\hline Mean $\left(\mu \mathrm{g} \mathrm{L}^{-1}\right)$ & 0.02 & 0.05 & 1.6 & 1.56 \\
\hline Median $\left(\mu \mathrm{g} \mathrm{L}^{-1}\right)$ & 0 & 0 & 0.69 & 0.79 \\
\hline s.d. $\left(\mu \mathrm{g} \mathrm{L}^{-1}\right)$ & 0.04 & 0.11 & 2.4 & 2.36 \\
\hline $95 \%$ Centile $\left(\mu \mathrm{g} \mathrm{L}^{-1}\right)$ & 0.05 & 0.3 & 5.0 & 6.33 \\
\hline $99 \%$ Centile $\left(\mu \mathrm{g} \mathrm{L}^{-1}\right)$ & 0.23 & 0.49 & 12.1 & 11.38 \\
\hline
\end{tabular}

In 315 serum samples out of 413 tested, $17 \beta-$ oestradiol was not detected above the decision limits of 0.013 and $0.011 \mu \mathrm{g} \mathrm{L}^{-1}(76 \%)$. Only in five samples the concentration of $17 \beta$-oestradiol exceeded $0.1 \mu \mathrm{g} \mathrm{L}^{-1}$, the recommended concentration for this compound proposed by the CRL Guidance Paper (5). For bulls, regardless of age, maximum concentration did not exceed half the value of the recommended concentration.

For young cows, maximum designated concentration was 0.165 , and for cattle over 18 months it reached a value of 1.120 . Mean $17 \beta$-oestradiol calculated concentration (included within the range of $0-\mathrm{CC} \alpha$ ) was very similar for young cows and bulls and did not exceed the decision limit of the methods. For heifer over 18 months mean oestradiol concentration was more than two times higher and amounted to $0.016 \mu \mathrm{g} \mathrm{L}^{-1}$. Calculated on the basis of a series of data, the 95 and 99 percentile values were two and three times higher for heifers than bulls.

Of the 413 serum samples tested for testosterone concentration, in $201(48.7 \%)$ the presence of this compound above the decision limits of 0.03 or $0.06 \mu \mathrm{g} \mathrm{L}-1$ was detected. For cows the average concentration of testosterone depended on age of animals, and was $0.02 \mu \mathrm{g}$ $\mathrm{L}^{-1}$ for animals under 18 months of age and 0.05 for older than 18 months of age. According to the presented data, $95 \%$ and $99 \%$ of the serum samples had testosterone concentration below $0.05-0.23 \mu \mathrm{g} \mathrm{L}^{-1}$ for cows $(0-18$ months of age) and $0.30-0.49 \mu \mathrm{g} \mathrm{L}^{-1}$ older than 18 months of age, respectively. 
Designated for bulls, mean concentration of testosterone was almost the same for young and old animals and was $1.60 \mu \mathrm{g} \mathrm{L}^{-1}$. Because a set of concentration values had a natural distribution, the 95 and 99 percentiles were determined and very similar values for bulls were obtained. The values did not depend on the age of the animals and were in the range of $5.00-11.38 \mu \mathrm{g} \mathrm{L}^{-1}$ and $6.33 \mu \mathrm{g} \mathrm{L}^{-1}-12.10 \mu \mathrm{g} \mathrm{L}^{-1}$ for cattle less than 18 months and older than 18 months of age, respectively.

\section{Discussion}

Confirmation of illegal administration of $17 \beta$ oestradiol and testosterone still involves difficulties associated with the distinction between exogenous and endogenous hormones (15). The main reason is the lack of discriminating power of the current screening method for serum samples and the absence of reliable and available confirmatory techniques (7). For compounds endogenously present in matrices of animal origin it is very important to determine their natural concentrations. Such research conducted on a large animal population gives opportunities to define the threshold values of concentrations that may constitute the criteria for the assessment of screening method results. The present study is a comprehensive overview of the natural occurrence of $17 \beta$-oestradiol and testosterone in a large number of serum samples $(\mathrm{n}=826)$ collected from cattle within five years in Poland. The population was representative of that for which the control of steroid abuse was aimed; the sex and age of the animals were taken into account. Because of the low number of samples taken from the calves ( $<50$ animals) no separate calculations for these animals were carried out. The serum samples were examined using two analytical methods; $30 \%$ samples were determined by ELISA and the remaining $70 \%$ by GC-MS method. Both methods have been validated and characterised by nearly identical parameters of detection and precision. These methods met the requirements established for the procedures used in studies of hormonal compounds (5), so the results obtained were reliable and independent of the method.

The 17 $\beta$-oestradiol levels in serum of animals below or equal 18 months of life and bulls older than 18 months were low and ranged between 0.003 and $0.006 \mu \mathrm{g} \mathrm{L}^{-1}$, below decision limits. The results for young cattle were consistent with previously presented in the literature (6). For older heifers average concentration was slightly higher than the decision limit of the applied methods, and was $0.016 \mu \mathrm{g} \mathrm{L}^{-1}$. The highest value for this age group of animals was $1.12 \mu \mathrm{g}$ $\mathrm{L}^{-1}$ and ten times exceeded the recommended threshold. Natural 17 $\beta$-oestradiol levels in cows varied greatly depending on the sexual cycle and pregnancy. Because the samples were taken from animals of varied age (from 1 month to several years), the range of detected oestradiol concentration was so wide.
It was demonstrated that $99 \%$ of heifer serum samples had $17 \beta$-oestradiol concentration below 0.09 $\mu \mathrm{g} \mathrm{L}^{-1}$, while in bulls, regardless of their age, it did not exceed $0.04 \mu \mathrm{g} \mathrm{L}^{-1}$. These results prove that recommended threshold values of $0.04 \mu \mathrm{g} \mathrm{L}^{-1}$ in serum can be still considered an acceptable upper limit for background levels for male animals independently of age, but for female animals $\leq 18$ months of age the value of $0.1 \mu \mathrm{g} \mathrm{L}^{-1}$ advisable in the CRL Guidance Paper is more appropriate. in older cows (>18 months), $99 \%$ serum samples had $17 \beta$-oestradiol concentration below $0.125 \mu \mathrm{g} \mathrm{L}^{-1}$, and this means that for older heifers slightly higher criteria should be set.

It must be emphasised that more than $60 \%$ of the samples examined for oestradiol and testosterone were taken from animals older than 18 months, for which the recommended concentration has not been set.

Naturally occurring testosterone levels vary according to sex, age, and breed of cattle, or whether the animals have been castrated or are pregnant $(6,16)$. The studies performed demonstrated that the concentration of testosterone in bulls is many times higher than in cows, both in respect of maximum values observed and average concentrations and set thresholds. In our study, natural testosterone levels in serum of young cows ( $\leq 18$ months) was $0.015 \mu \mathrm{g} \mathrm{L}^{-1}$, while median was 0 . Nakada et al. (14) reported results very similar to ours; the mean female plasma testosterone concentration between birth and puberty (43.3 weeks) ranged between 0.015 and $0.021 \mu \mathrm{g} \mathrm{L}^{-1}$. In cows above 18 months of age, the mean concentration was two and a half times higher than in young animals. The highest value in young cows was $0.26 \mu \mathrm{g} \mathrm{L}^{-1}$, well below the recommended threshold,

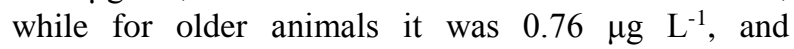
exceeded the maximum permissible concentration of $0.5 \mu \mathrm{g} \mathrm{L} \mathrm{L}^{-1}$. In bulls, mean testosterone concentration and median were almost the same for young and old animals. In the literature there are no data on testosterone levels in steers and heifers above 18 months of age. The value of threshold concentration determined for young cows was almost two times lower than the $0.5 \mu \mathrm{g} \mathrm{L}^{-1}$ set by the currently existing European Union guidelines. This recommended concentration would also be suitable for cows over 18 months of age, because $99 \%$ of serum samples taken from this group of animals had testosterone concentration below $0.49 \mu \mathrm{g} \mathrm{L}^{-1}$. The guidelines for positive decision limits proposed by Heitzman (9) and the CRL Guidance Paper (5), established at $30 \mu \mathrm{g} \mathrm{L}^{-1}$ for bulls above six months of life, seems to be considerably overestimated in the light of the threshold values below of $13 \mu \mathrm{g} \mathrm{L}^{-1}$ which were obtained in our study. With this study, we can evaluate the applicability of the recommended concentration (RC) for monitoring $17 \beta$-oestradiol and testosterone in bovine serum samples, advised by the EURL. No indications were obtained that the values applicable so far are invalid. Our research has shown that some of them can be applied to older animals. As the number of samples 
taken from cattle older than 18 months is significant, there is a need to set threshold criteria for $17 \beta$ oestradiol and testosterone for this group of animals.

Conflict of Interests Statement: The authors declare that there is no conflict of interests regarding the publication of this article.

Financial Disclosure Statement: The investigation was supported by the Polish Ministry of Agriculture and Rural Development (in the frame of Multiannual Programme "Control of the presence of prohibited substances in food of animal origin and undesirable substances in animal feed").

Animal Rights Statement: None required.

\section{References}

1. Angeletti R., Contiero L., Gallina G., Montesissa C.: The urinary ratio of testosterone to epitetosterone: a good marker of illegal treatment also in cattle? Vet Res Comm 2006, 30, 127-131.

2. Chen Y., Yazdanpanah M., Hoffman B.R., Diamandis E.P., Wong P-Y.: Rapid determination of serum testosterone by liquid chromatography-isotope dilution tandem mass spectrometry and a split sample comparison with three automated immunoassays. Clin Biochem 2009, 42, 484-490.

3. Council Directive 88/146/EEC. 1988 OJ L 070, 16.03.88, p. 1618.

4. Council Directive 96/23/EC. 1996 OJ L 125, 23.05.1996, p. 1032.

5. CRL Guidance Paper, CRLs view on state of the art analytical methods for national residue control plans. December 2007.

6. Doyle E.: Human safety of hormone implants used to promote growth in cattle. A review of the scientific literature. Food Research Institute, University of Wisconsin, July 2000, http://fri.wisc.edu/docs/pdf/hormone.pdf.

7. EURL Reflection paper: natural growth promoting substances in biological samples. RIKILT Wageningen UR, Wageningen, 2014.

8. Fiers T., Casetta B., Bernaert B., Vandersypt E., Debock M., Kaufman J.M.: Development of a highly sensitive method for the quantification of estrone and estradiol in serum by liquid chromatography tandem mass spectrometry without derivatization. J Chromatogr B 2012, 893-894, 57-62.

9. Heitzman R.J., Ed.: Veterinary drug residues. Residues in foodproducing animals and their products: Reference materials and methods. CEC, report EUR 14126 EN, 1992.

10. Le Bizec B.: Use of isotope ratio mass spectrometry to differentiate between endogenous steroids and synthetic homologues in cattle: a review. Anal Chim Acta 2013, 772, $1-15$.
11. Maume D., Le Bizec B., Pouponneau K., Deceuninck Y., Solere V., Paris A., Antignac J.P., Andre F.: Modification of $17 \beta$-estradiol metabolite profile in steer edible tissues after estradiol implant administration. Anal Chim Acta 2003, 483, 289-297.

12. Meyer H.H.D.: Biochemistry and physiology of anabolic hormones used for improvement of meat production. APMIS 2001, 109, 1-8.

13. Moal V., Mathieu E., Reynier P., Malthièry Y., Gallois Y.: Low serum testosterone assayed by liquid chromatography-tandem mass spectrometry. Comparison with five immunoassay techniques. Clin Chim Acta 2007, 386, 12-19.

14. Nakada K., Moriyoshi M., Kaka T., Watanbe G., Taya K.: Changes in concentrations of plasma immunoreactive folliclestimulating hormone, luteinising hormone, estradiol-17 $\beta$, testosterone, progesterone, and inhibin in heifers from birth to puberty. Dom Anim Endocrinol 2000, 18, 57-69.

15. Regal P., Cepeda A., Fente C.A.: Natural hormones in foodproducing animals: legal measurements and analytical implications. Food Production - Approaches, Challenges and Tasks, edited by Aladjadjiyan A. http://www.intechopen.com/ books/food-production-approaches-challenges-and-tasks/naturalhormones-in-food-producing-animals-legal-measurements-andanalytical-implications.

16. Scarth J., Akre C., Van Ginkel L., Le Bizec B., De Brabander H., Korth W., Points J., Teale P., kay J.: Presence and metabolism of endogenous androgenic-anabolic steroid hormones in meatproducing animals: a review. Food Addit Contam 2009, 26, 640671.

17. Scarth J.P., Clarke A., Teale P., Mill A., Macarthur R., Kay J.: Detection of endogenous steroid abuse in cattle: results from population studies in the UK. Food Addit Contam Part A 2011, $28,44-61$.

18. Scarth J.P., Kay J., Teale P., Akre C., Le Bizec B., De Brabander H.F., Vanhaecke L., Van Ginkel L., Points J.: A review of analytical strategies for the detection of 'endogenous' steroid abuse in food production. Drug Test Anal 2012, 4, 40-49.

19. Stephany R.W: Hormonal growth promoting agents in food producing animals. In: Doping in sports. Handbook of Experimental Pharmacology, edited by Thieme D., Hemmersbach P., Springer-Verlag, Heidelberg 2010, pp. 355367.

20. Stolker A.A.M., Groot M.J., Lasaroms J.J.P., Nijrolder A.W.J.M., Blokland M.H., Riedmaier I., Becker C., Meyer H.H.D., Nielen M.W.F.: Detectability of testosterone esters and estradiol benzoate in bovine hair and plasma following pour-on treatment. Anal Bioanal Chem 2009, 395,1075-1087.

21. Thakur R.A., Williard C., Rajasekaran A.: Using GC-MS/MS for superior sensitivity, specificity and precision in free testosterone analysis. Chromatography Today 2010, 3, 22-24.

22. Woźniak B., Matraszek-Żuchowska I., Żmudzki J.: Determination of $17 \beta$-oestradiol and testosterone in bovine serum with gas chromatography-mass spectrometry. Bull Vet Inst Pulawy 2011, 55, 755-759.

23. Wozniak B., Matraszek-Zuchowska I., Zmudzki J.: LC-MS/MS fast analysis of androgenic steroids in urine. Anal Bioanal Chem 2012, 403, 2965-2972. 